\title{
PREPARATION OF ANTI-Gm ANTIBODIES AND THEIR APPLICATION TO ENZYME-LINKED IMMUNOSORBENT ASSAY (ELISA) AND IMMUNOBLOTTING FOR Gm TYPING
}

\author{
Tetsuko KISHIDA \\ Department of Forensic Medicine, Medical College of Oita, \\ Hasama-cho, Oita 879-56, Japan
}

\begin{abstract}
Summary Gm typing has not yet come into widespread use in forensic science practice because of the short supply of anti-Gm sera and anti- $\mathrm{Rh}_{\mathbf{0}}$ sera indispensable for the conventional hemagglutination-inhibition method. To overcome the shortage of human anti-Gm sera, rabbit anti-Gm sera were prepared by immunization with normal IgG subclass proteins and their fragments. These heteroantisera-anti-Glm(2), anti-GIm(3), anti$\mathrm{G} 3 \mathrm{~m}(5)$, anti-G3m(16), and anti-G3m(21)-can distinguish the nine $\mathrm{Gm}$ phenotypes in the Japanese. Indicator cells alternative to anti- $\mathrm{Rh}_{0}$-coated cells were prepared by coupling IgG subclass proteins to red cells using the chromic chloride method. The $\operatorname{Glm}(2), \operatorname{Glm}(3)$, and $\mathrm{G} 3 \mathrm{~m}(21)$ antigens could be identified by this method. As a typing technique which involves no hemagglutination reaction, a solid-phase micro-ELISA (enzyme-linked immunosorbent assay) for Gm typing was developed. The GIm(3), G3m (16), and $\mathrm{G} 3 \mathrm{~m}(21)$ antigens could be detected with the rabbit anti-Gm sera and the monoclonal anti-G3m(21) antibody produced by the hybridoma technique. Satisfactory results were obtained by an immunoblotting technique with the monoclonal anti-G3m(21) antibody. Gm typing by the ELISA and immunoblotting with anti-Gm antibodies promise to become new typing methods alternative to the conventional method. Monoclonal anti-Gm is best suited for these methods because of its high titer and specificity.
\end{abstract}

\section{INTRODUCTION}

The first allotype of heavy chains of IgG molecules was discovered by Grubb (1956) and designated Gm(a) (Grubb and Laurell, 1956). Since then more than $20 \mathrm{Gm}$ factors have been described, but some of them were subsequently shown not to be distinct factors. At present both the numerical and the alphamerical nomenclature established by W.H.O. (1976) are used. 
Eighteen $\mathrm{Gm}$ factors are now recognized. They have been shown to originate from amino acid substitutions at one or two loci. The $\mathrm{Gm}$ factors are located on the constant region of the IgG molecule and inherited in fixed combinations, haplotypes, via codominant alleles. Gm haplotypes differ in different races. Therefore the frequencies of the haplotypes indicate the racial mixture rate in a particular population. The Gm system is also extremely useful in paternity testing since a much higher probability of excluding paternity is obtained with this system than with the other blood group systems. In the Japanese population, the exclusion rate is calculated at $40.7 \%$ when eight $\mathrm{Gm}$ factors, i.e., $\mathrm{Glm}(1), \mathrm{Glm}(2), \mathrm{Glm}(3), \mathrm{G} 3 \mathrm{~m}(5), \mathrm{G} 3 \mathrm{~m}$ (13), G3m(15), G3m(16), and $\mathrm{G} 3 \mathrm{~m}(21)$, are examined (Matsumoto, 1969).

In spite of these well-documented facts, Gm typing has not been widely applied to medicolegal practice. This is due to the shortage of specific anti-Gm sera and anti-R $\mathrm{h}_{0}$ sera with desired $\mathrm{Gm}$ specificities indispensable for the conventional hemagglutination-inhibition method. The anti-Gm sera in general use are of human origin and have low titers. An exhaustive screening test is necessary to obtain the anti-Gm sera needed for routine typing (Miyazaki et al., 1981). Early investigators attempted to prepare anti-Gm heteroantisera to replace human anti-Gm sera. Most of these antisera were raised in non-human primates by immunization with isolated myeloma proteins. They are not practicable for two reasons. Firstly, myeloma proteins of desired Gm types are not readily available. Secondly, not all forensic scientists can afford to use the animals.

Since the Japanese have nine $\mathrm{Gm}$ phenotypes resulting from the $G m^{1,2 l}, G m^{1,2,21}$, $G m^{1,3,5,13}$, and $G m^{1,13,15,16}$ haplotypes, (Matsumoto and Takatsuki, 1968), routine $\mathrm{Gm}$ typing in this population requires the detection of a minimum of four $\mathrm{Gm}$ factors, i.e., $\mathrm{Glm}(2)$, either $\mathrm{Glm}(3)$ or $\mathrm{G} 3 \mathrm{~m}(5), \mathrm{G} 3 \mathrm{~m}(16)$, and $\mathrm{G} 3 \mathrm{~m}(21)$. From this viewpoint, several attempts have been made in our Department to promote the routine use of $\mathrm{Gm}$ typing: 1. Preparation of anti-Gm sera by immunization of rabbits with normal IgG subclass proteins and their fragments (Tamaki et al., 1981; Kishida and Tamaki, 1983). 2. Preparation of indicator cells by coupling normal IgG subclass proteins to red cells by the chromic chloride method (Kishida et al., 1982). 3. Preparation of monoclonal anti-Gm antibody by the hybridoma technique (Tamaki et al., 1984). 4. Development of an enzyme-linked immunosorbent assay (ELISA) for Gm typing (Kishida and Tamaki, 1984). The present paper describes the results of the attempts collectively and reports a further study of the ELISA and the development of immunoblotting for Gm typing.

\section{MATERIALS AND METHODS}

Immunizing and coating antigens. The source of $\mathrm{IgG}$ was human plasma obtained from a blood center of the Japanese Red Cross. Sera were separated and the Gm phenotypes were determined by the conventional method. Anti- $\mathrm{Rh}_{0}$ sera, anti-Gm 
sera, and a panel of standard Gm sera were generously supplied by Prof. H. Matsumoto, Osaka Medical College. Commercially available anti- $\mathrm{Rh}_{0}$ sera (Biotest, Frankfurt am Main, W. Germany and DADE, Miami, FL) were also used. IgG of suitable $\mathrm{Gm}$ type was isolated by ammonium sulfate precipitation, followed by chromatography on a DE-52 (Whatman, Kent, U.K.) column. Its purity was checked by agar gel immunoelectrophoresis with anti-human serum (Cappel, Cochranville, PA) and anti-human IgG (homemade).

IgG subclass proteins were isolated by affinity chromatography on a protein ASepharose CL-4B (Pharmacia Fine Chemicals, Uppsala, Sweden) column (Duhamel et al., 1979). In brief, IgG3 was obtained by passing IgG solution through the column. IgG2 and IgG1 were isolated by $\mathrm{pH}$ gradient elution of the protein A-bound IgG (hereafter referred to as IgG1-rich IgG). Their purities were tested by Gm typing.

Fc and $F\left(a b^{\prime}\right)_{2}$ fragments were prepared by digestion of IgG with papain and pepsin (Sigma, St. Louis, MO.), respectively (Porter, 1959; Michaelsen and Natvig, 1971; Nisonoff et al., 1960), followed by affinity chromatography on protein ASepharose CL-4B. The fragments were checked for purity by immunoelectrophoresis and immunodiffusion with anti-human IgG, anti-Fab, and anti-Fc serum (Boehringer Institut, Marburg, W. Germany).

Rabbit anti-Gm sera. The details of the procedure were described in previous reports (Tamaki et al., 1981; Kishida and Tamaki, 1983), and only a brief outline is given here. Male albino rabbits were immunized by monthly injections of $3 \mathrm{mg} \mathrm{IgG}$, IgG subclass proteins, or their fragments of selected Gm type (Table 1). The antigens were emulsified in Freund's complete adjuvant (Nakarai Chemicals, Kyoto, Japan) and given by the subcutaneous and intramuscular routes. The animals were bled one week after each booster injection to be tested for antibody production.

Since the production rate of anti-Glm(2) was very low, immunization to $G \operatorname{lm}(2)$ was performed by the methods for the production of subclass-specific antibodies (Spiegelberg and Weigle, 1968; Giessen et al., 1974; Goosen et al., 1981). The rabbits were immune-paralysed by an intravenous injection of $10 \mathrm{mg} \operatorname{IgG2}(23)$. Three days later, the animals were injected subcutaneously and intramuscularly with $1 \mathrm{mg} \mathrm{Fc}$ of $\operatorname{IgGl}(1,2)$ mixed with complete adjuvant. One or two booster injections of Fc fragments were given at one-month intervals. The animals were test-bled three weeks after the first and one week after each booster injection. When no precipitating antibody against $\mathrm{IgG}$ was detected, the intravenous administration was repeated.

Rabbit antisera were inactivated at $56^{\circ} \mathrm{C}$ and absorbed with a mixture of human $\mathrm{O}, \mathrm{A}$, and $\mathrm{B}$ cells, and subsequently with $\mathrm{IgG}$ negative for the $\mathrm{Gm}$ antigen under study. The absorbed sera were tested for anti-Gm antibodies by the conventional hemagglutination-inhibition technique. When the desired antibody was produced, it was titrated against $0.2 \%$ suspensions of anti- $\mathrm{Rh}_{0}$-coated red cells.

The antibody-producing rabbits were exsanguinated. Anti-Gm antibodies were 
purified by affinity chromatography on Sepharose 4B (Pharmacia Fine Chemicals) coupled with $\mathrm{IgG}$ positive for the $\mathrm{Gm}$ factor concerned, followed by absorption with IgG negative for that factor.

Chromic chloride method. IgG subclass proteins were coupled to O red cells by the chromic chloride method modified by Loghem (Matsumoto, 1980). The proteins used were as follows: $\operatorname{IgG} 1$-rich $\operatorname{IgG}(1,2,21)$; $\operatorname{IgG} 1$-rich $\operatorname{IgG}(1,3,5,13)$; $\operatorname{IgG} 3(13$, $15,16) ; \operatorname{IgG} 3(21)$. One volume of protein solution $(0.1 \mathrm{mg} / \mathrm{ml})$, one volume of washed human $\mathrm{O}$ cells $(50 \%$ suspension), two volumes of saline, and one volume of $\mathrm{CrCl}_{3} \cdot 6 \mathrm{H}_{2} \mathrm{O}(0.05 \%)$ were mixed and the mixture was vigorously shaken for $10 \mathrm{~min}$. The cells were washed five times with saline. A $0.2 \%$ suspension of coated cells was made in $0.01 \mathrm{M}$ phosphate-buffered saline, $\mathrm{pH} 7.2$, containing $0.1 \%$ bovine serum albumin. The reactivity of these indicator cells was tested by the conventional method (Kishida et al., 1982).

Monoclonal antibody. A hybrid cell line secreting monoclonal anti-G3m(21) antibody was produced, as reported elsewhere (Tamaki et al., 1984), by a modification of the hybridoma technique of Galfre et al. (1977). Male BALB/c mice were immunized by an intramuscular injection of $100 \mu \mathrm{g} \operatorname{IgG3}(21)$ mixed with complete adjuvant. One or two booster injections were given at intervals of a month. Three days after the last boost, serum samples were tested for anti-G3m(21) by the same procedure used for testing rabbit antisera.

On the following day, $10^{8}$ spleen cells from the mice producing anti-G3m(21) were fused with $10^{7}$ mouse myeloma (NS-1) cells by the use of $50 \%$ polyethylene glycol 6000 (Koch-Light Laboratories, Colnbrook Berks, U.K.). The cells were washed with RPMI 1640 and mixed with $10^{7}$ mouse thymocytes as feeder cells. The cell mixture was suspended in $50 \mathrm{ml}$ RPMI 1640 with $15 \%$ fetal calf serum (FCS) and pipetted into 24-well culture plates. During the following 11 days, the cells were cultured in the HAT selection medium to keep only lymphocyte-NS-1 hybrid cells viable. The HAT medium contained $15 \% \mathrm{FCS}, 10^{-4} \mathrm{M}$ hypoxanthine, $4 \times 10^{-7} \mathrm{M}$ aminopterine, and $1.6 \times 10^{-5} \mathrm{M}$ thymidine in RPMI 1640. Then the HAT medium in the well was replaced stepwise by HT medium (HAT medium minus aminopterine).

Three weeks after fusion, culture supernatants were screened for anti-G3m(21) by the method described above. The hybrid cell producing the antibody was cloned by limiting dilution with normal medium in 96-well plates. Recloning of the cell was performed 19 days later, and the culture of the antibody-producing hybrid cell was expanded stepwise. After two weeks, $10^{7}$ hybrid cells were injected intraperitoneally into the mouse which had been intraperitoneally primed with $0.5 \mathrm{ml}$ pristane (Aldrich Chemical Company, Milwaukee, Wis.) 11 days before. Ascitic fluid was collected 12 days later, and the anti-G3m(21) contained was titrated against $0.2 \%$ suspensions of anti- $\mathrm{Rh}_{0}$-coated cells. Part of the antibody was affinitypurified and labeled with peroxidase (Nakane and Kawaoi, 1974).

Solid-phase micro-ELISA. According to the method of Voller et al. (1974), competitive ELISAs were performed on 20 samples each of Gm-positive and Gm-negative 
standard sera. The results were partly reported in the preceding paper (Kishida and Tamaki, 1984).

Microtiter wells were coated for $30 \mathrm{~min}$ with $100 \mu \mathrm{l}$ each of a dilute solution $(20 \mu \mathrm{g} / \mathrm{ml})$ of a standard antigen in $0.05 \mathrm{M}$ carbonate buffer, $\mathrm{pH} 9.6$. The antigens used were as follows: Fc of $\operatorname{IgGl}(1,2) ; \mathrm{F}\left(\mathrm{ab}^{\prime}\right)_{2}$ of $\operatorname{IgGl}(1,3) ; \operatorname{IgG}(1,13,15,16) ; \operatorname{IgG} 3$ (21). After the coating solution was shaken off, the wells were washed three times with $0.01 \mathrm{M}$ phosphate-buffered saline containing $0.05 \%$ Tween 20 (PBS-Tween), pH 7.4. To each well was added $80 \mu \mathrm{l}$ of a $1: 1$ mixture of a dilution of the anti-Gm reagent and a $1: 10$ dilution of a test serum in PBS-Tween which had been allowed to stand for $15 \mathrm{~min}$. On the basis of a preliminary experiment, each anti-Gm reagent had been diluted to have a titer of $1: 4$ against a $0.2 \%$ suspension of anti- $\mathrm{Rh}_{0}$-coated cells. After incubation for $30 \mathrm{~min}$, and washing with PBS-Tween, the wells were reacted with $80 \mu \mathrm{l}$ of a $1: 400$ dilution of peroxidase-labeled anti-rabbit IgG or antimouse IgG (Miles-Yeda, Rehovot, Israel) in PBS-Tween for $30 \mathrm{~min}$. The wells were similarly washed and reacted with $80 \mu \mathrm{l}$ of the substrate mixture containing $0.0028 \mathrm{M}$ $o$-phenylenediamine and $0.006 \%$ hydrogen peroxide in $0.05 \mathrm{M}$ phosphate $-0.024 \mathrm{M}$ citrate buffer, $\mathrm{pH}$ 5.0. The plate was left in the dark for $15 \mathrm{~min}$. The enzymic reaction was stopped by addition of $80 \mu \mathrm{l}$ of $12.5 \%$ sulfuric acid, and the absorbance of the colored product was measured on a MICROELISA Minireader MR590 (Dynatech, Alexandria, VA) at $490 \mathrm{~nm}$. Control wells received PBS-Tween instead of a serum sample. The percentage of inhibition for each sample was calculated as follows:

$$
\% \text { inhibition }=\frac{A T-A S}{A T}
$$

where $A s$ and $A T$ are the absorbances for the wells receiving the serum sample and PBS-Tween, respectively.

Alternatively, the wells coated with $\operatorname{IgG}(1,13,15,16,21)$ were reacted with a $1: 1$ mixture of an appropriate dilution of the enzyme-labeled monoclonal anti-G3m(21) and a $1: 10$ dilution of a test serum, followed by addition of the substrate buffer. The whole procedure was carried out at room temperature.

Immunoblotting. Twelve serum samples of known $\mathrm{Gm}$ type were subjected to isoelectric focusing (max. $1,500 \mathrm{~V}, 7 \mathrm{~mA})$ in a polyacrylamide gel $(10 \times 10 \times 0.05 \mathrm{~cm}$, $\mathrm{pH} \mathrm{5-8)} \mathrm{for} 2.5 \mathrm{hr}$. The focused proteins were transferred to a nitrocellulose membrane (Bio-Rad Laboratories, Richmond, CA) by close contact. After $1 \mathrm{hr}$, the membrane was removed from the gel and washed with $0.02 \mathrm{M}$ Tris $-0.5 \mathrm{M}$ saline (TBS), pH 7.5. Then the membrane was soaked in $3 \%$ bovine serum albumin in TBS for $30 \mathrm{~min}$, followed by washing with $0.05 \%$ Tween 20 in TBS (TBS-Tween). The membrane was then reacted with appropriately diluted monoclonal anti-G3m(21) in TBS-Tween for $1 \mathrm{hr}$. After similar washing, the membrane was reacted with a $1: 2,000$ dilution of peroxidase-labeled anti-mouse IgG in TBS-Tween for $1 \mathrm{hr}$. The membrane was washed quickly with distilled water, and immersed in the color development solution for $15 \mathrm{~min}$. The solution was prepared by mixing $30 \mathrm{mg}$ of 4-chloro-1-naphthol, $10 \mathrm{ml}$ of methanol, $50 \mathrm{ml}$ of TBS, and $25 \mu \mathrm{l}$ of $30 \%$ hydrogen 
peroxide. The enzymic reaction was stopped by soaking the membrane in distilled water. As a control experiment, IgG on the membrane was detected with antihuman IgG and enzyme-labeled anti-rabbit IgG.

\section{RESULTS AND DISCUSSION}

Rabbit anti-Gm sera were first prepared to ease the shortage of human anti-Gm sera. Table 1 summarizes the results of a series of immunizations. Immunizations with whole $\operatorname{IgG}$ proteins resulted in no production of anti-Gm antibody in spite of the ready production of anti-lgG precipitating antibodies. It was thought that only isotypic determinants on $\mathrm{IgG}$ molecules were recognized by the immunocompetent cells of the rabbit.

On the basis of this experience and the knowledge of the localization of Gm allotypic determinants on IgG molecules, IgG subclass proteins were used as immunogens. High-titer anti-G3m(5), anti-G3m(16), and anti-G3m(21) could readily be produced by immunization with $\operatorname{IgG} 3$ proteins. Anti-Glm(3) was formed upon immunization with $\operatorname{IgG} 1$-rich $\operatorname{IgG}(1,3,5,13)$. The antibody had a lower titer and production rate, however, than the anti-G3m antibodies did. In the light of these observations, rabbits were immunized with $F\left(a^{\prime}\right)_{2}$ fragments of $\operatorname{IgG1}$-rich $\operatorname{IgG}(1,3$, $5,13)$ or of $\operatorname{IgG1}(1,3)$. Although these immunizations gave satisfactory results, stimulation with the $\mathrm{F}\left(a b^{\prime}\right)_{2}$ of $\operatorname{IgG} 1(1,3)$ was more effective.

The production of anti-GIm(2) was the most difficult problem to solve. Immunization with $\operatorname{IgG1} 1$-rich $\operatorname{IgG}(1,2,21)$ or $\operatorname{IgG} 1(1,2)$ resulted in no production of anti-Glm(2). Thus Fc fragments were prepared as a further purified immunogen.

Table 1. Production of rabbit anti-Gm sera.

\begin{tabular}{|c|c|c|c|}
\hline Antibody sought & Immunogen (Gm type) & $\begin{array}{l}\text { Production } \\
\text { rate }\end{array}$ & $\underset{\text { titer }}{\text { Antibody }}$ \\
\hline \multirow[t]{6}{*}{$\operatorname{Anti}-\operatorname{Glm}(2)$} & $\operatorname{IgG}(1,2,21)$ & $0 / 10$ & - \\
\hline & IgGl-rich $\operatorname{IgG}(1,2,21)$ & $0 / 6$ & - \\
\hline & $\operatorname{IgG} 1(1,2)$ & $0 / 3$ & - \\
\hline & Fc of IgG1-rich $\operatorname{IgG}(1,2,21)$ & $1 / 4$ & 8 \\
\hline & $F_{c}$ of $\operatorname{IgG} 1(1,2)$ & $0 / 3$ & - \\
\hline & $\mathrm{Fc}$ of $\operatorname{IgG} 1(1,2)$ with tolerance induction & $2 / 10$ & 256 \\
\hline \multirow[t]{4}{*}{$\operatorname{Anti-GIm(3)}$} & $\operatorname{lgG}(1,3,5,13)$ & $0 / 3$ & - \\
\hline & $\operatorname{IgG1-rich} \operatorname{IgG}(1,3,5,13)$ & $2 / 8$ & 32 \\
\hline & $\mathrm{F}\left(\mathrm{ab}^{\prime}\right)_{2}$ of IgGl-rich $\operatorname{IgG}(1,3,5,13)$ & $2 / 2$ & 64 \\
\hline & $F\left(a b^{\prime}\right)_{2}$ of $\operatorname{IgG} 1(1,3)$ & $4 / 6$ & 256 \\
\hline Anti-G3m(5) & $\operatorname{lgG} 3(5,13,21)$ & $2 / 4$ & 128 \\
\hline Anti-G3m(16) & $\operatorname{IgG} 3(13,15,16)$ & $4 / 6$ & 512 \\
\hline Anti-G3m(21) & $\operatorname{lgG} 3(21)$ & $10 / 16$ & 512 \\
\hline
\end{tabular}


Though an anti-GIm(2) antibody with a low titer was formed upon immunization with the $F c$ of $\operatorname{IgG} 1$-rich $\operatorname{IgG}(1,2,21)$, immunization with the Fc of $\operatorname{IgG} 1(1,2)$ thereafter ended in failure. These results suggest that $\mathrm{Gm}$ factors on $\mathrm{IgGl}$, especially the Glm (2), are low-immunogenic in rabbits. It was not until immunization with the Fc of $\operatorname{IgG} 1(1,2)$ following immune-paralysis with $\operatorname{IgG} 2(23)$ that anti-Glm(2) was successfully produced.

The rabbit anti-Gm sera thus obtained can distinguish the nine Gm phenotypes in the Japanese. Since immunization of rabbits with normal IgG is a practicable method, one of the obstacles to the general use of $\mathrm{Gm}$ typing has been overcome. These heteroantisera, however, are of no use in the conventional method unless anti- $\mathrm{Rh}_{0}$ sera are available for sensitization of red cells. Alternative indicator cells were prepared by coupling purified IgG subclass proteins to red cells using the chromic chloride method. The $\operatorname{Glm}(2), \operatorname{Glm}(3)$, and $\mathrm{G} 3 \mathrm{~m}(21)$ antigens could be detected with these indicator cells. But no $\mathrm{G} 3 \mathrm{~m}(16)$ antigen was detectable by this method. Furthermore the indicator cells were not reliable in respect of sensitivity and reproducibility. The need was felt for development of a new typing technique involving no hemagglutination reaction. The solid-phase micro-ELISA in microtiter plates seemed to be a solution.

Gm typing by ELISA requires high-titered, monospecific anti-Gm antibodies. Rabbit anti-Gm sera must be affinity-purified to minimize nonspecific adsorption to the solid-phase. Their recoveries are rather low. Moreover antibody titers are sometimes too low to be used in ELISA. As a novel approach to these problems, the preparation of monoclonal anti-Gm antibodies was planned.

Six of ten mice immunized with $\operatorname{IgG} 3(21)$ produced anti-G3m(21). A screening test after cell fusion revealed that all culture supernatants from 144 wells contained anti-IgG antibodies. Only one of them exhibited anti-G3m(21) activity. After two cycles of cloning and expansion of the culture, the anti-G3m(21)-producing hybridomas were grown intraperitoneally, and 5-7 $\mathrm{ml}$ ascitic fluid was obtained from one mouse. The ascitic fluid contained an extremely high titer $(1: 32,768)$ of anti-G3m(21) antibody compared with the rabbit antisera. Supposing that $60 \mathrm{ml}$ of antiserum can be obtained from one rabbit, $1 \mathrm{ml}$ mouse ascitic fluid is equivalent to the antiserum obtainable from one rabbit. In addition, this approach has a great advantage in that, once established, the hybrid cell line continues to secrete the antibody semipermanently.

Gm typing by ELISA was carried out with the rabbit anti-Gm sera and the monoclonal anti-G3m(21) antibody. Figure 1A shows the typical results of an indirect ELISA for $\operatorname{Glm}(3)$ typing with the rabbit anti-Glm(3), each dot representing the percentage inhibition value for a single sample. The percentage inhibition values for $\operatorname{GIm}(3)$-positive samples averaged 68.95, and those for $\operatorname{Glm}(3)$-negative samples 21.26. The positive and negative samples could be clearly distinguished from each other. Similar results were obtained in repeated ELISAs. An indirect ELISA with the rabbit anti-G3m(16) also gave satisfactory results (Fig. 1B). Neither 


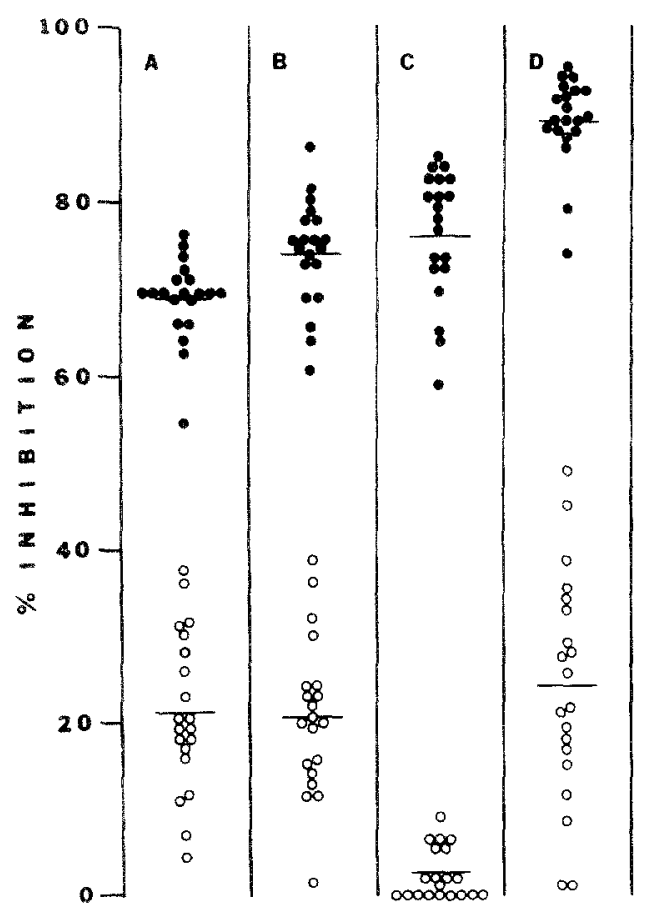

Fig. 1. Percentage inhibition values in ELISAs. A, indirect ELISA for GIm(3) with rabbit anti-Glm(3), mean value for positive sample $=68.95 \pm 4.94$, mean value for negative sample $=21.26 \pm 9.14$; $B$, indirect ELISA for G3m(16) with rabbit anti$\mathrm{G} 3 \mathrm{~m}(16)$, mean value for positive sample $=74.14=5.61$, mean value for negative sample $=20.67 \pm 8.91 ; C$, indirect ELISA for $G 3 m(21)$ with monoclonal anti$\mathrm{G} 3 \mathrm{~m}(21)$, mean value for positive sample $=76.35 \pm 7.25$, mean value for negative sample $=2.68 \pm 3.68$; D, direct ELISA for G3m(21) with enzyme-labeled monoclonal anti-G $3 \mathrm{~m}(21)$, mean value for positive sample $=89.20 \pm 5.08$, mean value for negative sample $=24.20 \pm 13.69$. Each dot represents the value for a single sample. - positive samples; 0 , negative samples. Horizontal bars correspond to mean values.

the $\mathrm{G} \operatorname{lm}(2)$ nor the $\mathrm{G} 3 \mathrm{~m}(2 \mathrm{I})$ antigen, however, could be identified by the ELISA with the rabbit antisera because nonspecific adsorption to the well was intractable.

More clear-cut distinction between the positive and negative samples could be made with the monoclonal anti-G3m(21) antibody than with the rabbit anti-Gm sera (Fig. 1C). The mean values for $\mathrm{G} 3 \mathrm{~m}(21)$-positive and $\mathrm{G} 3 \mathrm{~m}(21)$-negative samples were 76.35 and 2.68 , respectively. It was probably due to a minimal degree of nonspecific adsorption. The monoclonal antibody was also superior to the rabbit antisera in respect of reproducibility.

Figure 1D represents the results of a direct ELISA with the enzyme-labeled monoclonal anti-G3m(21). Although individual variations were found in some degree, positive and negative reactions could be readily distinguished. 
The ELISA made it possible to detect three of the four $\mathrm{Gm}$ factors that must be identified for routine typing in the Japanese population. If enough monoclonal anti-Gm antibody is available, the direct ELISA with enzyme-labeled monoclonal antibody is more suitable for practical use in that it saves time and work.

Both ELISA and monoclonal antibody have found wide application in immunologic work recently. Nevertheless, there have been very few reports of their application to Gm typing. Francois-Gerard and Hoste (1984) and Fletcher et al. (1984) independently devised ELISAs for Glm(3) typing of sera and bloodstains with monoclonal anti-GIm(3) antibody. They used a double-sandwich method or a double-antibody method and obtained satisfactory results. With the monoclonal anti-G3m(21), however, a double-sandwich ELISA ended in failure. This was probably due to the quantitative difference between $\operatorname{IgG1}(70 \%)$ and $\operatorname{IgG} 3(4 \%)$ in the total IgG of normal serum. For the same reason, it is improbable that a doubleantibody ELISA can be used in G3m(21) typing. Thus, competitive ELISAs are favorable for detection of $\mathrm{G} 3 \mathrm{~m}$ antigens.

In regard to practical use, these ELISA systems have a drawback. The doublesandwich ELISA requires two kinds of first antibodies, and the competitive ELISA needs standard antigens for coating wells in addition to the first antibody. It was expected that immunoblotting technique would make the antigen coats unnecessary.

Figure 2 depicts the immunoblotting patterns of $\operatorname{IgG}$ proteins after isoelectric focusing. They were detected with anti-human IgG and peroxidase-labeled antirabbit IgG (Fig. 2A), or with the monoclonal anti-G3m(21) and enzyme-labeled anti-mouse IgG (Fig. 2B). Although the IgG proteins gave a columnar pattern and no clear bands because of their high heterogeneity, yet $\mathrm{G} 3 \mathrm{~m}(21)$-positive samples could be distinguished from G3m(21)-negative ones by this method. This suggests that the immunoblotting technique, which requires antibodies but no coating antigens, may make $\mathrm{Gm}$ typing as routine as the phenotyping of other serum proteins in all forensic science laboratories. This method also seems suitable for mass screening tests because it requires a very small amount of the first antibody.

No G3m(21) antigen could be detected when serum samples were directly applied to nitrocellulose membrane. It was thought that albumin and other serum proteins prevented the adsorption of IgG3 which occupies only $4 \%$ of the $\operatorname{IgG}$ in normal serum. A possibility exists that Glm antigens can be detected by this 'dotblotting' technique.

The $\mathrm{Gm}$ system is extremely useful in personal identification. A considerable amount of research has been made on the detection of $\mathrm{Gm}$ antigens in bloodstains, saliva, semen, vaginal secretions, urine, etc. Until very recently, investigators depended entirely on the hemagglutination-inhibition technique. The largest problem in such inhibition assays was the optimum dilution of the particular anti-Gm serum. Using ELISAs with monoclonal antibody, Francois-Gerard and Hoste (1984) and Fletcher et al. (1984) could detect the GIm(3) antigen in bloodstains up to 22-24 months old. Since only a minute amount of test material is needed, both ELISA 


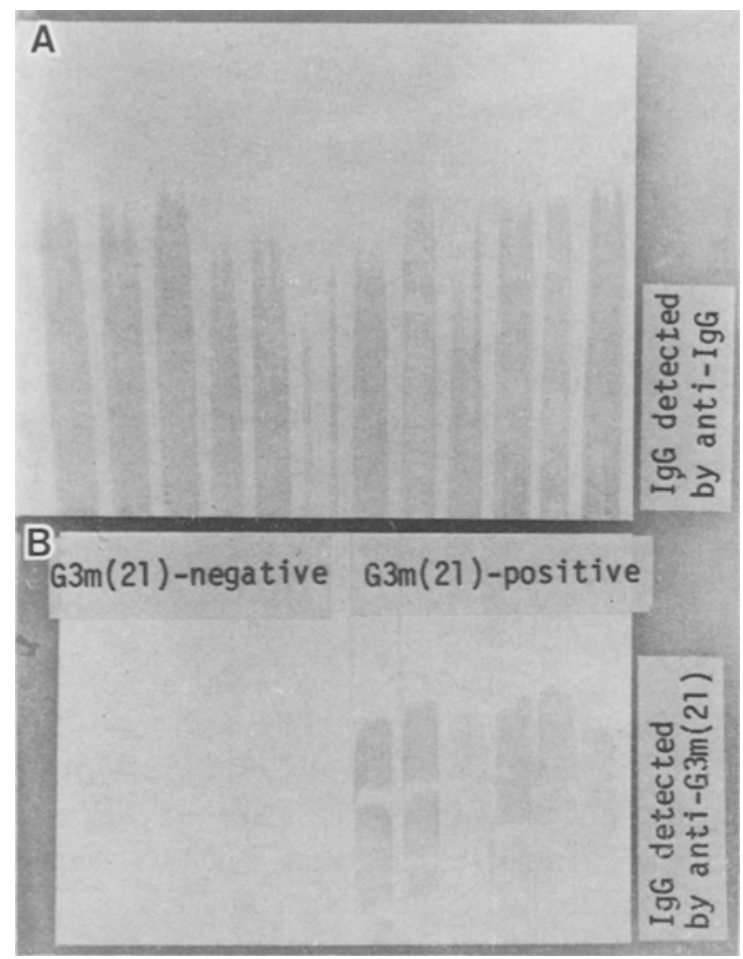

Fig. 2. Immunoblotting patterns of IgG proteins after isoelectric focusing. A, patterns detected with anti-human IgG and enzyme-labeled anti-rabbit IgG; B, patterns detected with monoclonal anti-G3m(21) and enzyme-labeled anti-mouse IgG.

and immunoblotting seem to be suitable for the detection of $\mathrm{Gm}$ antigens in bloodstains and body fluids.

Although still at an experimental stage, ELISA and immunoblotting promise to become new typing methods which will be substituted for the method in current use. If they are put to practical use, Gm typing ought to come into wide use in the practice of forensic medicine. The surest way to this final goal appears to produce monoclonal antibodies to the other $\mathrm{Gm}$ antigens.

Acknowledgements. The author wish to express her thanks to Prof. H. Matsumoto of Osaka Medical College for the gift of anti- $\mathrm{Rh}_{0}$ sera, anti-Gm sera, and a panel of standard Gm sera. She is also grateful to Prof. Y. Tamaki for his constant interest and encouragement in this study.

This work was supported in part by Grant-in-Aid for Scientific Research Nos. 457179, 56570244, 58480206 , and 58570267 from The Ministry of Education, Science and Culture of Japan.

\section{REFERENCES}

Duhamel, R.C., Schur, P.H., Brendel, K., and Meezen, E. 1979. pH gradient elution of human IgG1, IgG2 and IgG4 from protein A-Sepharose. J. Immunol. Methods 31: 211-217. 
Fletcher, S.M., Dorrill, M.J., and Dolton, P. 1984. Bloodstain allotyping: An ELISA method for Glm(3). Dev. Biol. Stand. 57: 381-384.

Francois-Gerard, C. and Hoste, B. 1984. A double-sandwich ELISA technique for Gm typing with a mouse monoclonal antibody. 18th Congr. Int. Soc. Blood Transf. Munich, July 22-27, 1984.

Galfre, G., Howe, S.C., Milstein, C., Butcher, G.W., and Howard, J.C. 1977. Antibodies to major histocompatibility antigens produced by hybrid cell Jines. Nature 266: 550-552.

Giessen, M. van, Lange, B. de, and Lee, B. van der 1974. The production of precipitating antiglobulin reagents specific for the subclasses of human IgG. Immunology 27: 655-663.

Goosen, P.C.M., Beekhuizen, S. van, Droogh, C., and Lange, G. de 1981. Preparation of antibodies against subclasses of human IgG. J. Immunol. Methods 40: 339-344.

Grubb, R. 1956. Agglutination of erythrocytes coated with "incomplete" anti-Rh by certain rheumatoid arthritic sera and some other sera. Acta Pathol. Microbiol. Scand. 39: 195-197.

Grubb, R. and Laurell, A.B. 1956. Hereditary serological human serum group. Acta Pathol. Microbiol. Scand. 39: 390-398.

Kishida, T., Fukuda, M., Takahashi, N., and Tamaki, Y. 1982. Gm typing without anti-D coats. Jpn. J. Legal Med. (in Japanese) 36: 1000.

Kishida, T. and Tamaki, Y. 1983. An improved method for the production of antisera to Glm allotypes. Jpn. J. Human Genet. 28 : 269-272.

Kishida, T. and Tamaki, Y. 1984. Gm typing by enzyme-linked immunosorbent assay (ELISA). Z. Rechtsmed. 93: 23-27.

Matsumoto, H. and Takatsuki, K. 1968. Gm factors in Japan: Population and family studies. Jpn. J. Human Genet. 13: 10-19.

Matsumoto, H. 1969. The application of Gm systems in paternity cases (II). Jpn. J. Legal Med. (in Japanese with English abstract) 23: 41-49.

Matsumoto, H. 1980. personal communication.

Michaelsen, T.E. and Natvig, J.B. 1971. Isolation and characterization of IgG subclass proteins and $\mathrm{FC}$ fragments from normal human IgG. A method for utilizing 'non a' and 'non g' as genetic markers. Immunochemistry 8: 235-242.

Miyazaki, T., Yamamoto, N., Sato, S., and Hirota, T. 1981. Anti-Gm antisera (SNagg) detected among Japanese. Jpn. J. Legal Med. (in Japanese) 35: 130.

Nakane, P.K. and Kawaoi, A. 1974. Peroxidase-labeled antibody. A new method of conjugation. J. Histochem. Cytochem. 22: 1084-1091.

Nisonoff, A., Wissler, F.C., Lipman, L.N., and Woernley, D.L. 1960. Separation of univalent fragments from the bivalent rabbit antibody molecule by reduction of disulfide bonds. Arch. Biochem. Biophys. 89: 230-244.

Porter, R.R. 1959. The hydrolysis of rabbit $\gamma$-globulin and antibodies with crystalline papain. Biochem. J. 73: 119-126.

Spiegelberg, H.L. and Weigle, W.O. 1968. The production of antisera to human $\gamma \mathrm{G}$ subclasses in rabbits using immunological unresponsiveness. J. Immunol. 101: 377-380.

Tamaki, Y., Kishida, T., Shibata, K., Takahashi, N., and Fukuda, M. 1981. Preparation of anti$\mathrm{Gm}$ sera by immunization of rabbits with protein A-fractionated normal IgG proteins from Japanese: Further study. J. Immunol. Methods 45: 177-182.

Tamaki, Y., Takahashi, N., Kishida, T., and Ishikawa, K. 1984. Production and characterization of monoclonal anti-G3m(g) antibody. Jpn. J. Legal Med. (in Japanese) 38: 152-154.

Voller, A., Bidwell, D.E., Huldt, G., and Engall, E. 1974. A microplate method of enzyme-linked immunosorbent assay and its application to malaria. Bull.W.H.O. 51:209-211.

W.H.O. 1976. Review of the notation for the allotypic and related markers of human immunoglobulins. WHO meeting on human immunoglobulin allotypic markers. J. Immunogenet. 3: $357-362$. 